\title{
CAN CORPORATE SOCIAL STRATEGY CREATE SHARED VALUE TOWARD CREATIVE BUSINESS? "VOLVO SOCIAL STRATEGY MODEL"
}

\author{
Ishak Kherchi $^{1}$, Fellague Mohamed ${ }^{1}$, Haddou Samira Ahlem ${ }^{1}$ \\ date of paper receipt: \\ date of sending to review: \\ date of review receipt: \\ 06.03.2019. \\ 08.03.2019. \\ 20.03.2019. \\ Review Article \\ doi: 10.2478/eoik-2019-0016 \\ UDK: 6587.8:339.138]:005.336.3
}

${ }^{1}$ University of Hassiba ben Bouali Chlief, Faculty of Economics, Commerce and Management Science, Algeria

\begin{abstract}
Purpose: This paper aims to provide corporate social strategies as an entrance to create shared value, in addition to that we aims to provide a theoretical and practical contributions that ground understanding the concept of creating shared value.

Design/methodology/approach:

The authors analyze a single case study of Volvo corporation. The objective is to evaluate whether the corporate social strategies can yields to a shared value creation.

Findings:

We found that corporate social strategies followed by Volvo Corporation yields to a shared value creation.

Research limitations/implications:

This single case study provides an entrance to create shared value; however, more research is needed to find other entrances.

Practical implications:

The paper has practical implications that relate to the design of shared value model. We provide practical well known strategies that could be apply by corporations to reach shared value creation. Originality/value:

A unique view of corporate social strategy and creating shared value concept.
\end{abstract}

Keywords: Creating shared value, corporate social strategy, social value, business value, business competitiveness, Volvo corporation

JEL: M14. 


\section{INTRODUCTION}

Our world faces urgent many global challenges, such as depletion of natural resources and uneven distribution of wealth, poor nutrition, not enough health care, pollution, access to water, climate change and deforestation.

Despite the effort of social organizations, corporate social responsibility, social entrepreneurship; we still have so much trouble to deal with these social and environmental problems, because the complexity, size and scale of these challenges require a role for business.

One of the best leading companies in creative business to solve and environmental problems is Volvo. For the Volvo Group, facing these problems and creating social and economic value involves efforts to move both business and society forward, enhancing Volvo competitiveness while simultaneously advancing environmental and social conditions of the societies in which Volvo operate.

However creating shared value for Volvo require social strategies to follow on portfolio activities in order to provide products and service which create value for society and lead Volvo to a competitive business.

The fundamental problem of this study is related to the way Volvo creates business value and social value, using corporate social strategy, so the question is:

How implementing corporate social strategy creates shared value and lead Volvo to a competitive business?

Objective of the study:

Through this study we aims to provide corporate social strategies as an entrance to create shared value, in addition to that we aims to provide a theoretical and practical contributions that ground understanding the concept of creating shared value towards an innovative business. This study is based on qualitative research; an approach that seeks to describe, decode and translate phenomena in terms of meaning rather than frequency therefore we do not need to provide hypotheses.

\section{LITERATURE REVIEW}

\subsection{SHARED VALUE DEFINITIONS:}

According to Porter .M.E \& Kramer.M ;Shared value can be defined as policies and operating practices that enhance the competitiveness of a company while simultaneously advancing the economic and social conditions in the communities in which it operates (Porter .M.E \& Kramer.M 2011).

Creating shared value is an investment in company sustainable competitiveness, achieving economic and social goals. It implies company striving to create shared value in both environments external and internal, and preferably along several dimensions (Porter .M.E \& Kramer.M 2011).

The CSV concept or 'shared value' is an alternative strategy that simultaneously creates both social and business values by reconceiving products/markets, redefining productivity in the value chain, and enabling local cluster development. It can help firms to better respond to societal, environmental, and market needs as well as business activities (Awale R, Rowlinson.S, 2015)

We consider creating shared value as new concept in business that allows creating social value while simultaneously moving business forward and leading to a competitive business.

does not necessarily lead to business success and facilitate future growth and development of the firm. CSV concept is a new way of thinking in management - an alternative strategy to achieve long-term competitiveness that focuses on integration of a social purpose into companies' business operations (Awale R, Rowlinson.S, 2015). 


\subsection{STEPS TO CREATE SHARED VALUE}

Shared value can be created by reconceiving products and services to meet societal demands, by redefining productivity in the value chain and by enabling local cluster development: ( Brønn.P.S, Romantis,Zerfass.A 2016)

\subsubsection{RECONCEIVING PRODUCTS AND SERVICES}

Products and services should be conceived and produced for meeting social needs and thus they should create social benefits. For instance, the food industry, rather than stimulating more consumption, should focus its interests and strengths on driving better nutrition and health issues. The potentialities of this approach to develop new services and products can be even more significant in poor and disadvantaged countries, where the needs are greater than those of developed countries. For companies this means that societal needs should be constantly monitored and incorporated in the managerial processes concerning R\&D and production.

\subsubsection{REDEFINING PRODUCTIVITY}

The value chain is affected by externalities, such as water use, working conditions and fair treatment, which can enhance the costs of production. Taking into account societal issues permits companies to redefine their concept of productivity from a shared value perspective. For instance rethinking logistics systems in the shared value perspective means improving energy utilization through technology investments, such as reducing shipping distances, recycling. All these practices help companies transform the value chain, cutting costs and reinforcing the mutual relationships with partners and stakeholders.

\subsubsection{ENABLING LOCAL CLUSTER DEVELOPMENT}

Finally, shared value can be created by enabling local cluster development. Clusters are geographical concentrations of actors (suppliers, logistical infrastructures, institutions, universities, service providers, trade associations and so on), which support a company and its processes. Firms can create shared value and improve their productivity, by building local clusters and addressing their gaps in specific areas such as logistics, training or market organization. Managerial practices driven by transparency and openness principles create favourable conditions for building clusters, which enhance the benefits for companies and their competitiveness.

We see that reconceiving products and markets allows to develop products regard to society's needs and this what rise the demand on these products, in the same time redefining productivity in the value chain allows to save energy, water, cost and create value for both society and business, then, enabling local cluster development which help to provide infrastructure around creating shared value

\subsection{LEVELS OF SHARED VALUE}

As we mentioned above shared value created by reconceiving product and markets, redefining productivity in the value chain and enabling cluster development, however how every step of shared value creation contribute in business and social value creation.in order to analyse that we provide the three levels of shared value creation as we see in Table 1. 
Table 1. Three levels of Shared Value Creation

\section{LEVELS OF SHARED VALUE \\ Reconceiving product and markets: \\ How targeting unmet needs drives incremental revenue and profits}

Redefining productivity in the value chain:

How better management of internal operations increases productivity and reduces risks

Enabling cluster development:

How changing societal conditions outside the company unleashes new growth and productivity gains
BUSINESS RESULTS

Increased revenue

Increased market share

Increased market growth

Improved profitability

Improved productivity

Reduced logistical and operating costs

Secured supply

Improved quality

Improved profitability

Reduced costs

Secured supply

Improved distribution infrastructure

Improved workforce access

Improved profitability
SOCIAL RESULTS

Improved patient care

Reduced carbon footprint

Improved nutrition

Improved education

Reduced energy use

Reduced water use

Reduced raw materials

Improved job skills

Improved employee

incomes

Improved education

Increased job creation

Improved health

Improved incomes

Source: Porter et al Measuring Shared Value How to Unlock Value by Linking Social and Business results, FSG USA, 2013, P3.

We see that each level of shared value contribute in the creation of business and social value targeting unmet needs drives incremental revenue and creat social value, a better management of internal operations increases productivity and reduces risks and save water and energy that the society need. In addition to that changing societal conditions outside the company unleashes new growth and productivity gains.

\subsection{CORPORATE SOCIAL STRATEGY}

There exists no generally accepted typology of corporate social strategies. Three different generic social strategies typically emerge from the literature: product differentiation, cost leadership, and strategic interaction between the firm and its regulators (either government or industry).

These three generic strategies permit an integration of the economic and social objectives of the firm by using social action to create value for stockholders (HUSTED.B.W, ALLEN.David.A,2001). The purpose of social strategy is to create value for the firm, especially economic value.

Social strategy normally involves the investment of capital, whether financial or human, in order to achieve social objectives (HUSTED.B.W, ALLEN.David.B 2001). Social strategy focuses on activities where the social dimension of corporate activity may be joined with the economic dimension in such a way as to enhance both economic and social value creation (HUSTED.B.W, ALLEN.David.B 2001). Generally speaking such strategy creates value for the firm via the creation of a firm reputation or some form of product differentiation (Fombrun, C. and C. Shanley,1990). Value can be also created through the development of new products or services that incorporate a social component or through the creation of entirely new markets (HUSTED.B.W, ALLEN. David.B 2001). Social strategy is focused on understanding the conditions under which project maximization and social performance are congruent (HUSTED.B.W, ALLEN.David.B 2001).

Corporate Social strategy often involves the introduction of needed products and services to underserved and poorly understood markets as well as the development of new products and services with social attributes (Kanter, R. M. 1999).Social strategy shares with business strategy the pursuit of profit, but it is not simply a specific kind of business strategy.

We see that corporate social strategy focus on addressing social needs and problems that generates profit for the firm and yields to a competitive business. 


\section{CONCEPTUAL FRAMEWORK}

\subsection{CORPORATE SOCIAL STRATEGY TO CREATE SHARED VALUE}

Michael Porter (1980) identified two generic strategies to achieve a competitive advantage: differentiation and cost leadership. Forest Reinhardt (1999) applied Porter's framework and added a third generic strategy; strategic interaction.

Husted. B.W, Allen.D.B (2001) develops a framework for formulating social strategy by provided three social strategies extant in the literature: differentiation, cost leadership, and strategic interaction to create competitive advantages that are valuable, rare and imperfectly imitable.

Porter and Kramer (2011) provided shared value as a new concept in business to improve corporate competitiveness by advancing their business and social conditions simultaneously. However porter and Kramer (2011) do not specify how to create shared value within portfolio activities and business strategy level.

We see that a Husted and Allen (2001) social strategy tool is crucial in creating shared value and formulating a strategic model to create economic value and social benefit. We used Husted and Allen (2001) social strategies; differentiation social strategy, cost leadership social strategy, strategic interaction to show the process of these strategies in achieving porter (2011) shared value concepts and formulate strategic model of creating shared value.

Figure 1. Social strategy to create shared value

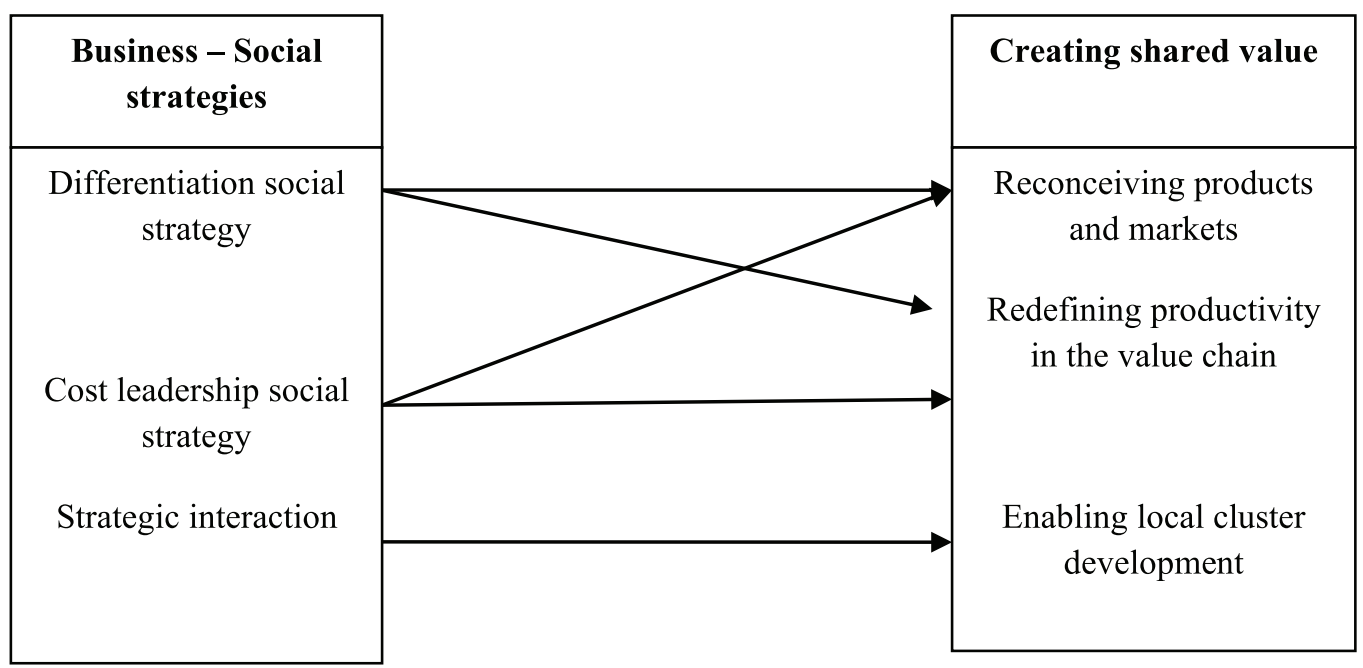

Source: Authors (2019).

\subsubsection{COST LEADERSHIP SOCIAL STRATEGY AND RECONCEIVING PRODUCTS AND MARKETS:}

A cost leadership social strategy may emerge where i rms discover that cost savings are available through process innovation (Hart, S. L. 1995). There exists evidence of the capacity of firms to innovate in response to social opportunities and threats (Kanter, R. M. 1999)

Cost leadership social strategy occurs where firms discover cost savings that are available through process innovation (HUSTED.B.W, ALLEN.David.B 2001). Firms can reconceive products to adress social needs by decreasing costs.

\subsubsection{COST LEADERSHIP SOCIAL STRATEGY AND REDEFINING PRODUCTIVITY IN THE VALUE CHAIN:}

The value chain depicts all the activities a company engages in while doing business and when societal progress and productivity in the value chain are congruent, the shared value is far greater 
than traditionally believed (Moon.H.G, parc.J, 2011).

For Firm to develop collaborative, problem-solving relationships with a variety of stakeholders, supplier-buyer cooperation can facilitate innovation leading to cost leadership, but such cooperation can occur only if the firm has well developed resources for stakeholder integration as well as continuous innovation (HUSTED.B.W, ALLEN.David.B 2001). Cost savings may occur through the wise management of relationships with suppliers who are committed to similar social objectives (HUSTED.B.W, ALLEN.David.B 2001).

Firms can redefine the productivity in the value chain for cost saving by reduced electricity reduced direct $\mathrm{CO} 2$ emissions, reduce the quantity of water waste, increase reuse material recycling and energy recovery.

Cost saving may occur through Improving energy, water and resource efficiency across the value chain, Minimizing logistical intensity, Improving employee health and safety, Enhancing the productivity and wages of lower income employees, Recruiting that represents the diversity of customers and the communities where a company operates.

Other main resources for cost saving to redefine the productivity in the value chain are; Economies of scale, production technique (Process innovation, Re-engineering of business processes), input costs (Location advantages, Ownership of low-cost inputs, Nonunion labor, Bargaining power) (GRANT.R.M. 2010).

\subsubsection{DIFFERENTIATION SOCIAL STRATEGY AND RECONCEIVING PRODUCTS AND MARKETS}

In the case of product differentiation, the social objectives of the firm differentiating existing products or developing new products and markets (HUSTED.B.W, ALLEN.David.B 2001).

Differentiation social strategy allows firms to reconceiving products through process innovation and providing new products with regard to society's needs.

\subsubsection{DIFFERENTIATION SOCIAL STRATEGY AND REDEFINING PRODUCTIVITY IN THE VALUE CHAIN}

In order to apply the differentiation social strategy Firms need to redefine the productivity in the value chain by Constructing a value chain for the firm and the customer. Identify the drivers of uniqueness in each activity, Select the most promising differentiation variables for the firm, Locate linkages between the value chain of the firm and that of the buyer (GRANT.R.M, 2010).

3.1.5.Strategic interaction and enabling local cluster:

the strategic interaction social strategy specii cally incorporates nonmarket actions in creating rent-seeking opportunities through the use of regulation and/or industry standards. However, nonmarket actions may also include activities such as social network development, political contributions, and community service (Shaffer, B. , Quasney, T. J. , and Grimm , C. M. 2000).

According to (Husted.B.W, Allen.D.B 2001) the strategic interaction social strategy involves the strategic use of regulation and/or self-regulation in order to create rent-seeking opportunities for the firm. Researchers have demonstrated that firms can use government and industry regulation as a means to obtain competitive advantage with respect to other firms that are less well positioned to comply with such standards.

Firm use a strategic interaction social strategy to influence public policy so that the regulator imposes such standards on the entire industry. Such strategies often provide policy makers with information about new policy or build constituencies to support such initiatives (Hillman, A. J. \& Hitt, M. A. 1999), this what enabling local cluster. 


\section{METHOLOGY}

We used the qualitative research. The qualitative research can be defined as an approach that seeks to describe, decode and translate phenomena in terms of meaning rather than frequency .Qualitative research allows the researcher to gather information and do an in-depth exploration of issues, and therefore follows a less structured format with fewer respondents than quantitative methods (Bellenger, DN, Bernhardt, KL \& Goldtucker, JL 1989). This qualitative research approach is appropriate for our study because this kind of study required a lot of information and high understanding for the situations, initiatives and social activities

Within the qualitative research, we use a case study approach to investigate the idea of shared value in Volvo company through social strategy initiatives. We aim to provide a theoretical and practical contribution to enhance the understanding of how corporate social strategy leads to shared value creation.

We collect data and information based from Volvo reports, online meeting with Volvo founders, and observations; the authors analyze a single case study of volvo company. The objective is showing how shared value concept applied using corporate social strategy.

\section{VOLVO SOCIAL STRATEGY MODEL}

\section{WHO IS VOLVO?}

\subsection{VOLVO GROUP}

The Volvo Group is one of the world's leading manufacturers of trucks, buses and construction equipment, drive systems for marine and industrial applications and aerospace components. The Group also provides complete solutions for financing and service. In 1927, the first series-produced Volvo car rolled off the production line at the Gothenburg plant and in 1928 the first truck was produced (Hoque.N,Uddin.M.H,Ibrahim.Md,Mamun.A 2014).

The Volvo Group employs about 115,000 people, has 65 production facilities in 20 countries and sells its products in more than 190 markets. In 2011 annual sales of the Volvo Group amounted to about SEK 310 billion. The Group's market share of sales are 39\% in Europe, 19\% in North America, $11 \%$ in South America, 24\% in Asia, 7\% in rest of the World (Hoque.N,Uddin.M.H,Ibrahim. Md,Mamun.A 2014).

The Volvo Group was one of the first companies to become a signatory to the United Nations' Global Compact when it was launched in 2001. The Group is committed to the principles of the initiative, and they are integrated into its Group policy and core governance document: the Volvo group code of conduct (The Volvo group annual and sustainability report 2011).

The Volvo Group's vision is to become the world leader in sustainable transport solutions by creating value for customers in selected segments, pioneering products and services for the transport and infrastructure industries, driving quality, safety and environmental care, and working with energy, passion and respect for the individual The Volvo group csr and sustainability report, 2011)

\section{HOW VOLVO CREATED SHARED VALUE}

Volvo designed multi-pronged approaches to provide holistic solutions to social and business problems:

Volvo Reconceive products and markets using differentiation social strategies, by doing that Volvo provided new UD Quester truck, Trucks offer 24-hour roadside assistance, new heavy-duty truck range, Volvo Construction Equipment's (Volvo CE) excavators.

As we see in figure 2, Volvo Redefined productivity in the value chain using cost leadership social 
strategies, this allowed Volvo to Decrease energy consumption, reduced electricity reduced direct $\mathrm{CO} 2$ emissions, adding value and uniqueness in each activity, Construct a value chain for the firm and the custom, reduce the quantity of water waste, increase reuse material recycling and energy recovery.

In addition to that Volvo Enable local cluster development through Strategic interaction with World Economic Forum, Japan Automobile Manufacturers Association (JAMA),American Trucking Associations, American Public Transportation Association, National Marine Manufacturers Association, European Association of Internal Combustion Engine Manufacturers (Euromot), Truck and Engine Manufacturers Association (EMA) in the US.

Figure 2. VOLVO Business - Social strategies To Create shared value

\begin{tabular}{|c|c|c|}
\hline $\begin{array}{c}\text { Business - Social } \\
\text { strategies }\end{array}$ & & $\begin{array}{c}\text { Creating shared } \\
\text { value }\end{array}$ \\
\hline $\begin{array}{l}\text { Differentiation- social } \\
\text { strategies }\end{array}$ & $\begin{array}{l}\text { Volvo new UD Quester truck, Trucks offer } \\
\text { 24-hour roadside assistance, new heavy-duty } \\
\text { truck range,Volvo Construction Equipment's } \\
\text { (Volvo CE) excavators }\end{array}$ & $\begin{array}{c}\text { Reconceiving } \\
\text { products and markets }\end{array}$ \\
\hline $\begin{array}{c}\text { Cost leadership- social } \\
\text { strategies }\end{array}$ & $\begin{array}{l}\text { Decreasing energy consumption, reduced } \\
\text { electricity reduced direct } \mathrm{CO} 2 \text { emissions, } \\
\text { adding value and uniqueness in each } \\
\text { activity,Construct a value chain for the firm } \\
\text { and the custom, reduce the quantity of water } \\
\text { waste, increase reuse material recycling and } \\
\text { energy recovery. }\end{array}$ & $\begin{array}{l}\text { Redefining } \\
\text { productivity in the } \\
\text { value chain }\end{array}$ \\
\hline Strategic interaction & $\begin{array}{c}\text { World Economic Forum, Japan Automobile } \\
\text { Manufacturers Association } \\
\text { (JAMA),American Trucking } \\
\text { Associations, American Public } \\
\text { Transportation Association, National Marine } \\
\text { Manufacturers Association, European } \\
\text { Association of Internal Combustion Engine } \\
\text { Manufacturers (Euromot), Truck and Engine } \\
\text { Manufacturers Association (EMA) in the } \\
\text { US. }\end{array}$ & $\begin{array}{c}\text { Enabling local cluster } \\
\text { development }\end{array}$ \\
\hline
\end{tabular}

Source: Authors (2019).

\subsection{DIFFERENTIATION SOCIAL STRATEGY AND RECONCEIVING PRODUCTS AND MARKETS}

The Group offers a wide range of products and services customized for different markets and needs. For example, Volvo new UD Quester truck range has been designed to meet specific needs of customers in growth markets in Asia and beyond.

In Europe, Volvo Trucks and Renault Trucks offer 24-hour roadside assistance to keep customers moving. Volvo remanufacturing centers enable us to reduce the cost of spare parts for customers worldwide (Supporting productivity, www.volvo.com, 11/10/2017). 
In 2013, Volvo made great strides towards goals with the launch of Quester the Group's new heavyduty truck range designed, priced and equipped especially for growth markets and businesses. The first target markets are Thailand, Indonesia, Malaysia and China, with India and several other growth markets across the world to follow (Sustainability report, 2013).

In August 2013, the Volvo Group launched into the Chinese market two new types of teeth for the buckets of two models of Volvo Construction Equipment's (Volvo CE) excavators. They are part of a new range of components that includes economically priced ground-engaging tools, such as side cutters, side shrouds, segments and bolt-on edges. Volvo CE's new products for mediumto light-duty applications generally offer lower initial purchase costs and adapted wear-resistant specifications (Sustainability report, 2013).

We see that Volvo reconceiving products regarding to society's needs and focus on meeting specific buying needs and behaviors in Emerging markets by providing economically priced ground engaging tools, useful truck which could solve some social needs and problems.

\subsection{REDEFINING PRODUCTIVITY IN THE VALUE CHAIN}

The Volvo Group takes a whole value chain approach to developing long-term, sustainable competitiveness. Volvo takes responsibility for the operations within its direct control and strives to create mutually beneficial partnerships with Volvo business partners.

Redefining productivity in the value chain require a set of steps like Product development, purchasing, production, distribution and service, products in use, re-use.in addition to that Volvo treat other aspects.

2-3-Differentiation social strategy and redefining productivity in the value chain:

Volvo redefined the productivity in the value chain Using Differentiation social strategy in areas of product development, purchasing, production, distribution and service as follows:

Product development is based on the needs of customers, legislation, changes in society and new technology.

Volvo strives to have long-term relationships with suppliers of technologically advanced components. Around $95 \%$ of the Volvo Group spending on automotive products comes from suppliers certified in accordance with ISO 14001 or its equivalent.

All the Volvo Group's wholly-owned production facilities have third-party audited quality certificate and $98 \%$ have environmental certificates. All Volvo Group-owned dealers are covered by the Group's environmental requirements and $90 \%$ of Volvo distribution centers are certified according to ISO 14001.

2-4-Cost leadership social strategy and redefining productivity in the value chain:

Volvo redefined the productivity in the value chain Using Cost leadership social strategy in areas of Energy efficiency, Carbon emissions from production, Waste and water.

\subsubsection{ENERGY EFFICIENCY}

The Group's 2015 total energy consumption amounted to 2,106 GWh, a reduction of $70 \mathrm{GWh}$ compared to 2014. The main activity behind the reduction was increased energy efficiency. By reducing energy, Volvo both reduce costs and lower emissions. Between 2005 and 2015, the Volvo Group decreased energy consumption in Volvo own production processes by roughly $20 \%$ in absolute terms. This means that the energy cost for 2015 has decreased with more than SEK $500 \mathrm{M}$ thanks to energy efficiency activities (The Volvo group annual and sustainability report, 2015). The accumulated saving is significantly larger. For example, Volvo Construction Equipment has reduced electricity consumption by focusing on idle time, by changing behavior, electricity consumption during idle time at the six largest plants has been reduced by $19 \%$ in 2015 and by 39\% overall since 2012. This is equivalent to heating 343 houses in Sweden for a full year (The Volvo group annual and sustainability report, 2015).. Volvo energy efficiency index, which compares 
energy consumption with net sales, was 6.9 MWh/SEK M in 2015, compared with 7.9 MWh/SEK $\mathrm{M}$ in 2014. The 2015 energy efficiency index has thereby improved 13\% since 2014 (Improving our energy efficiency, www.volvo.com, 12/10/2017).

We see that Cost leadership social strategy decreased energy consumption, electricity consumption and this what increasing energy efficiency index and allowed Volvo to redefine the productivity in the value chain and lead to focus more on source of productivity improvement and Reduce production costs.

\subsubsection{CARBON EMISSIONS FROM PRODUCTION}

In 2015, direct CO2 emissions from the Volvo Group's production facilities decreased from 231,000 tons to 221,000 tons. About $40 \%$ of Volvo total energy consumption came from low-carbon renewable sources, including hydropower electricity and biomass heating (McMullen.C 2016). The Volvo Group has carbon-neutral facilities in Ghent, Belgium, as well as Vara, Tuve and Braås in Sweden. Additionally we have facilities buying 100\% of their electricity produced from landfill gas instead of fossil fuels (The Volvo group annual and sustainability report, 2015).

Volvo redefine the productivity in the value chain by focusing on main aspect that provide value for the society and save cost for the group such as decreasing energy consumption, reduced electricity reduced direct $\mathrm{CO} 2$ emissions, reduce the quantity of water waste, increase reuse material recycling and energy recovery.

\subsection{STRATEGIC INTERACTION ENABLING LOCAL CLUSTER THROUGH PARTNERSHIP}

Volvo believe it is more efficient to work in partnership with key stakeholders, and that Volvo social impact will be increased by working together with partners sharing mutual goals. Over the years, Volvo has developed partnerships with customers, government officials, non-governmental organizations, local decision makers, educational and community groups (Sustainability report 2014).

Knowledge of legislation, trends and best practice, both in Volvo industry and the wider world, is essential to the Volvo Group's ability to actively meet needs and identify new business opportunities. The Group is a signatory of the UN Global Compact, a member of the World Wide Fund for Nature (WWF) Climate Savers Program and participates in many trade and industry forums including: (Moving our business forward, www.volvo.com, 14/10/2017).

European Automobile Manufacturers' Association (ACEA)

Committee for European Construction Equipment (CECE)

Truck and Engine Manufacturers Association (EMA) in the US

Japan Automobile Manufacturers Association (JAMA)

Association of Equipment Manufacturers in the US

American Trucking Associations

American Public Transportation Association

Each year, the Volvo Research and Educational Foundations (VREF) make major investments in dedicated research projects supporting the development of sustainable transport systems in large urban areas worldwide. Volvo also devotes extensive resources to traffic safety research, partnering with key industry players, universities and governments for greater efficiency (Sustainable transport solutions research www.volvo.com, 14/10/2017)..Volvo also make an Academic Partner Program (APP), the basic principle behind this program is long-term strategic collaboration with leading universities in areas. This collaboration with universities is key for the Volvo Group to keep driving innovation in the area of transport solutions of mutual interest. The Volvo Group is currently working on a joint initiative within the Academic Partner Program (APP) together with Chalmers University of Technology and Mälardalen University in Sweden, Penn State University in the United 
States, as well as the waste recycling company Renova. The initiative aims to develop a robot that interacts with the refuse truck and its driver to accomplish the work Volvo continues the successful cooperation with the academic world www.volvo.com, 14/10/2017).

Volvo strategically interacts and developed partnerships with deferent parts including; customers, government officials, non-governmental organizations, local decision makers, educational and community groups and this what enabled local cluster. Following business social strategies; Cost leadership social strategy, Differentiation social strategy and strategic interaction, Volvo reconceiving product and markets, redefining productivity in the value chain and building clusters through partnership and lead to shared value creation.

\section{VOLVO SOCIAL STRATEGIES CREATED SHARED VALUE}

\subsection{OTHER ASPECTS OF VOLVO SOCIAL STRATEGIES TO CREATE SOCIAL VALUE}

Volvo engages in activities related to core business and operating context where Volvo can use unique expertise, knowledge and skills to address social and environmental challenges. All activity is guided by Volvo corporate core values of quality, safety and environmental care and aims to support Volvo vision. The Volvo Group is most active in the areas of skills development, traffic safety, education, environmental protection and disaster relief.

\subsubsection{DEVELOPING SKILLS}

The Volvo Group conducts a variety of professional training programs in emerging and established markets worldwide that facilitate employment opportunities within the local community and secure the long term development of Volvo business, Volvo encouraged 100,000 employees to get involved in promoting safety awareness sessions for children in their immediate environment (Educating and developing skills, www.volvo.com, 15/10/2017).

\subsubsection{TRAINING SCHOOLS IN AFRICA}

The Volvo Group is planning to invest a total SEK $30 \mathrm{M}$ to introduce vocational training schools in 10 African countries, in partnership with the Swedish International Development Cooperation Agency (Sida) and the US Agency for International Development (USAID) (Hedouin.S .2015).

The Volvo Group has an ambition to grow revenue in Africa by 25 percent between 2013 and 2015. The schools will be set up in countries that are both business-critical for the Volvo Group and eligible for development grants from both Sida and USAID.

\subsubsection{WORLD FOOD PROGRAM}

The United Nations World Food Program (WFP) works to combat hunger by guaranteeing access to food in the poorest parts of the world Reliable trucks are vital to the WFP's logistics and Renault Trucks are a key partner for carrying supplies in extreme conditions. Renault Trucks initiated a five-month volunteer program to train WFP mechanics in six East African countries, concluding March 2013. Volvo provided a mobile training unit and a team of expert technicians to give WFP mechanics onsite training in the most advanced maintenance techniques (Training of World Food Program technicians in East Africa, www.volvo.com, 16/10/2017).

\subsubsection{THE VOLVO STEP}

The Volvo Step is a one-year, paid vocational training program in industrial production created specifically for unemployed young people aged 18 to 22. The Volvo Step takes place at 13 sites across Sweden and provides both theoretical and practical learning experience $15 \%$ of all food in Europe is delivered by a truck from the Volvo Group (Ripa.M. 2014). 


\subsubsection{IMPROVING TRAFFIC SAFETY}

Through educational programs and sponsorship, the Volvo Group participates in different initiatives to increase safety and reduce the number of traffic accidents.

\subsubsection{INCREASING SAFETY THROUGH AWARENESS AND TRAINING}

Volvo run traffic and site safety programs for drivers and operators all over the world, including: (Increasing safety through awareness and training www.volvo.com, 24/10/2017).

- The Transform program in Brazil has been running since 1998 and has been replicated in Peru.

- Driver training programs run jointly in India have trained more than 159,000 drivers.

- Operator training run by Volvo Construction Equipment in India trained close to 2,000 operators in 2015 and the total trained since the start 2007 is above 10,200.

- Volvo Driver Academy is a demo training project initiated in China for drivers to drive more safely and efficiently.

\subsubsection{PROFESSIONAL DRIVER PROGRAMS IN SOUTH AMERICA}

The Volvo Group's transform program has trained over 900 professional drivers in vehicle safety technology and safe driving behavior skills since its launch in Brazil (2008) and Peru (2010).

The program offers a five-day intensive training on appropriate vehicle handling and better use of its safety elements onsite or at Volvo Group facilities or dealerships. It also motivates drivers to consider the emotional impacts of traffic accidents on their families (Improving traffic safety, www. volvo.com, 24/10/2017).

In India, Volvo have trained over 110,000 drivers in total. Volvo train at least two drivers for every Volvo truck and bus sold around 35,000 to date and we collaborate with Volvo joint venture partner, Eicher, and government agencies on award-winning truck and bus driving and safety programs (Improving traffic safety, www.volvo.com, 24/10/2017).

\subsubsection{RESPONDING TO DISASTER}

Volvo responds to disasters in various ways, depending on the situation and the most appropriate use of Volvo expertise, skills and resources. While Volvo cannot contribute to all cases, Volvo do try to assist several each year. During 2013, Volvo offered disaster relief assistance following: (Responding to disasters, www.volvo.com, 24/10/2017).

- Typhoon Haiyan in the Philippines

- The Yàan earthquake in China

- Flash floods in Uttarakhand, northern India.

\subsubsection{DISASTER RELIEF SUPPORT}

2013 included donations of money, clothing and equipment to assist organizations dealing with the Yaan earthquake, Uttarakhand floods and Typhoon Haiyan (Corporate social responsibility, 2013)

\subsubsection{CARING FOR THE ENVIRONMENT}

Environmental care is one of Volvo corporate core values and aim to establish programs that encourage society to take a greater interest in the environment globally and locally: (Sustainability report, 2013)

\subsubsection{VOLVO ENVIRONMENT PRIZE}

The Volvo Environment Prize foundation was established in 1988 and has become one of the world's most prestigious environmental prizes. It is awarded annually to people who have made outstanding scientific discoveries within the area of the environment and sustainable development The prize consists of a diploma, sculpture and a cash sum of SEK 1.5 M and is presented at a ceremony in Stockholm, Sweden. 


\subsubsection{VOLVO ENVIRONMENTAL CENTER}

Volvo Environmental Center in Brazil lies amid remnants of ancient rainforest that is home to 1,500 botanical species, over 250 bird and hundreds of other animal species

\subsubsection{UP-CYCLING DESIGN ARTS CAMPAIGN}

With the support of the China Resource Recycling Association, Volvo Construction Equipment unveiled 'City Garden' - the first conceptual piece of art designed from scrap machinery parts - to launch a new campaign in Shanghai during 2013. The campaign encourages people to transform scrap machinery parts into urban artwork and explore new approaches to environmental protection and city enhancement.

\subsection{CORPORATE SOCIAL STRATEGIES LEAD VOLVO TO A COMPETITIVE BUSINESS}

Volvo Social strategies made a high impact on business value in terms of; net sales, cash flow, gross income, Return on Equity, Return on shareholders' equity and other value indicators: (The Volvo group annual and sustainability report, 2014)

. Net sales

Net sales increased by SEK 312,515 billion compared with prior year 2014 out of which approximately SEK 282,948 billion and sek 272,622 billion in 2013.

- Operating income

Operating income increased by SEK 23,318billion compared with prior year out of 2014 which approximately SEK 5,824 billion and sek 7,138 billion in 2013.

. Operating cash flow, Industrial Operations

Operating cash fl ow, Industrial Operations increased by SEK 18.3 billion compared with prior year out of 2014 which approximately SEK 6.4 billion and sek 1.5 billion in 2013 .

. Gross income

Gross income increased by SEK 71,862 billion compared with prior year out of 2014 which approximately SEK 62,937 billion and sek 60,118billion in 2013.

. Income for the period

Income for the periodincreased by SEK 15,099 billion compared with prior year out of which approximately SEK 2,235billion.

. Cash flow from operating activities

Cash flow from operating activities increased by SEK 25,858 billion compared with prior year out of which approximately SEK8,737 billion.

. Operating income

Operating income increased by SEK 17.5 billion (300\%) compared with prior year out of which approximately SEK 8.9 billion

. Return on shareholders' equity\%:

Return on shareholders' equity\%, increased by SEK 18.4 billion compared with prior year out of which approximately SEK 2.8 billion.

. Gross margin, \%:

Gross margin, \% increased by SEK 22.2 billion compared with prior year out of 2014 which approximately SEK 21.3 billion and sek 21.1 in 2013.

. Return on Equity, \%

Return on Equity, \% increased by SEK 13.4 billion compared with prior year out of 2014 which approximately SEK 12.5 billion and sek 12, 1 in 2013.

We see that most business performance indicators have improved and bring value for the group, in addition to that, there are others business indicators that rise the value of the group, we provide some these indicators as follows: (The Volvo group annual and sustainability report, 2014)

Volvo Buses has sold more than 2,300 hybrid buses in over 20 countries In 2015, Volvo delivered 
207,475 trucks from Volvo wholly-owned truck operations and 8,825 buses, 44,718 units of construction equipment, 17,413 marine engines and 15,295 industrial engines from Volvo Group operations.

As part of "The Best Commercial Vehicles 2015", in Stuttgart, Germany, Volvo Trucks received five awards for the Volvo FH/ FH16 and Volvo FM. Volvo FH won the Truck of the Year title in Poland as well as in the Czech Republic and Slovakia.

In November, Volvo Penta's revolutionary Forward Drive (FWD) was honored at the Berlin Boat Show with the Best of Boats Special Award. Earlier in the year Boating Industry, a US boating business magazine, selected FWD as one of the top products of the year. FWD also won the Innovation Award at Miami International Boat Show.

The Electricity partnership, where Volvo is one of the main participants, was recognized by the European Association for Renewable Energy, Eurosolar, for being the best example for 2015 of sustainable public transport using renewable energy.

In 2015, a total of 207,475 trucks where delivered from the Group's wholly-owned operations, an increase of 2\% compared with 203,124 trucks in 2014. Deliveries increased in Europe and North America while they were flat in Asia and declined in South America and Other markets.

In 2015, net sales in the truck operations increased by $12 \%$ to SEK 213,978 M $(190,904)$. Adjusted for changes in exchange rates, net sales increased by $2 \%$.

Volvo is number 2 in heavy-duty diesel engines.

Volvo is number 1 in marine diesel engines.

Volvo is number 2 in heavy-duty trucks

Volvo is number 2 in buses for target segments.

Volvo is number 4 in construction equipment.

The previous Volvo social programs and efforts moved society forward and improve most business performance indicators (moved Volvo group business forward), Volvo become number 1 in marine diesel engines and number 2 in heavy-duty trucks and buses for target segments.

\section{CONCLUSION AND RECOMMENDATIONS}

Both social strategy and shared value aims to provide economic and social value, we can create shared value by implementing corporate social strategies; cost leadership strategy, differentiation strategy and strategic interaction.

Volvo have developed a model to reach shared value using social strategies such as, differentiation strategy to reconceiving products and markets, cost leadership strategy to Redefining Productivity in the Value Chain and strategic interaction for enabling local cluster development.

In addition to that; Volvo used other aspects of social strategy that helped to create shared value; Developing skills, Training schools in Africa, World Food Program, Improving traffic safety Increasing safety through awareness and training Professional driver programs In South America, Increasing safety through awareness and training School safety programs, Raising awareness, rewarding best practice, Responding to disaster and Caring for the environment programs.

All of these social strategies lead Volvo to a competitive business and improve all performance indicators which rise the value of the group. We hope this article serves to illustrate the scale of that opportunity, and triggers discussion and innovation around ways to capitalize on it. 


\section{REFERENCES}

[1] Porter .M.E \& Kramer.M (2011): Creating Shared Value, Harvard Business Review ,P66.

[2] Lentjushenkovaa.O, Lapinab( 2015): Intellectual Capital Investments: Company's Additional Expenditures or Creating Shared Value? 15th International Conference at Brno University of Technology, Faculty of Business and Management, May 28-29, Brno, Czech Republic Perspectives of Business and Entrepreunership Development,p6.

[3] Awale R, Rowlinson.S(2015): An ExploratoryStudy of a CSVConcertfor AchievingFirm Competiiveness in Hong Kong Construction Firms, Thirty-First Annual Conference, Lincoln, Volume 2.

[4] Awale.R , Rowlinson.S (2015): A CSV Concept to Adress Health and Safety Issues and Achieve Firm Competitivenes in the Hong Kong Construction Industry, Proceedings of CIB W099 Benefitting Workers and Society through Inherently Safe(r) Construction Belfast, Northern Ireland, p245.

[5] Brønn.P.S, Romantis,Zerfass.A (2016): Book Series: Advances in Public Relations and Communication management, Emerald Group Publishing Limited, p 189.

[6] HUSTED.B.W, ALLEN.David.A (2001): Toward a Model ofCorporate Social Strategy Formulation, Paper presented at the Social Issues in Management Division, Academy of Management,p10.

[7] HUSTED.B.W, ALLEN.David.B (2001): Corporate Social Strategy: Stakeholder Engagement and Competitive Advantage, cambridge universit y press, p14.

[8] Fombrun, C. and C. Shanley: 1990, 'What's in a Name? Reputation Building and Corporate Strategy', Academy of Management Review 33(2), 233-258.

[9] Kanter, R. M. 1999. From spare change to real change . Harvard Business Review , 77 (3): 122 $-132$

[10] Hart , S. L. 1995 . A natural-resource based view of the i rm . Academy of Management Review , 20 (4): $986-1014$.

[11] Kanter , R. M. 1999 . From spare change to real change . Harvard Business Review , 77 (3): 122 -132 .

[12] Moon.H.G, parc.J (2011): Journal of International and Area Studies, Volume 18, Number 2, pp.49-64

[13] GRANT.R.M (2010 ): Contemporary Strategy Analysis, John Wiley \& Sons Ltd, Seventh Edition, p231.

[14] Shaffer, B. , Quasney, T. J. , and Grimm, C. M. 2000 . Firm level performance implications of nonmarket actions. Business and Society, 39 (2): $6-143$.

[15] Hillman, A. J. \& Hitt, M. A. 1999. Corporate political strategy formulation: A model of approach, participation, and strategy decisions. Academy of Management Review, 24 (4): 825-842.

[16] Bellenger, DN, Bernhardt, KL \& Goldtucker, JL 1989, 'Qualitative research techniques: Focus group interviews', in Focus group interviews: A reader, eds TJ Hayes \& CB Tatham, American Marketing Association, Chicago.

[17] Hoque.N,Uddin.M.H,Ibrahim.Md,Mamun.A (2014): Corporate Social Responsibilities (CSR) as a Means of Materializing Corporate Vision: A Volvo Group Approach, Asian Social Science; Vol. 10, No. 11,p260,DOI: 10.5539/ass.v10n11.

[18] The Volvo group annual and sustainability report (2011): Global Compact A decade as a signatory to the Global Compact, $p 99$.

[19] The Volvo group csr and sustainability report (2011):Towards sustainable transport solutions Shaping the future of transport,p4

[20] Supporting productivity http://www3.volvo.com /investors/finrep/sr13/en/creatingvalue/ movingsocietyforwar/supportingproductiv/supporting-producti.html, 11/10/2017.

[21] Sustainability report (2013), op, cit, p42.

[22] Improving our energy efficiency, http://www3.volvo.com/investors/finrep/sr14/en/ responsiblebehavior/valuechainsustainab/environmentalimpact/energy/improving-our-energ. html, 12/10/2017. 
[23] McMullen.C (2016): Key Takeaways from Volvo Group's New Sustainability Report,http:// waste360.com/waste-reduction/key-takeaways-volvo-group-s-new-sustainability-report.

[24] Sustainability report (2014): Creating shared value, p13.

[25] Moving our business forward, www3.volvo.com/investors/finrep/sr13/en/creatingvalue/ movingourbusinessfo/moving-our-business.html, 14/10/2017.

[26] Sustainable transport solutions research, www3.volvo.com/investors/finrep/sr14/en/ sustainabletranspor/futuretransportsolu/research/sustainable-transpo.html,15/10/2017.

[27] Volvo continues the successful cooperation with the academic world, http://news. volvogroup.com/2017/10/14/volvo-continues-the-successful-collaboration-with-the-academicworld/\#sthash.Y9r2833t.dpufnews.volvogroup.com/2016/10/14/volvo-continues-the-successfulcollaboration-with-the-academic-world/,16/10/2017.

[28] Educatinganddevelopingskills,www3.volvo.com/investors/finrep/sr14/en/creatingsharedvalue/ societalengagement/educationandskillsd/educating-and-devel.html,22/10/2017.

[29] Hedouin.S (2015): Public Transport Sustainability: BRT \& Electro Mobility, brought to you by Volvo,p72

[30] Training of World Food Program technicians in East Africa (2012), www3.volvo.com/investors/ finrep/sr12/en/societyengagement/professionaltrainin/trainingofworldfood/training-of-world-f. html

[31] Ripa.M (2014): We can make a difference in Africa,news.volvogroup.com;we-can-make-adifference-in-africa,23/10/2017.

[32] Increasing safety through awareness and training (2012), www3.volvo.com/investors/finrep/sr14/ en/sustainabletranspor/safersolutions/trafficanddriversaf/increasing-safety-t.html,24/10/2017.

[33] Improving traffic safety (2013),www3.volvo.com/investors/finrep/sr13/en/creatingvalue/ movingsocietyforwar/engagingwithsociety/improvingtrafficsaf/improving-traffic-s.html

[34] Improving traffic safety (2013), www3.volvo.com/investors/finrep/sr13/en/creatingvalue/ movingsocietyforwar/engagingwithsociety/improvingtrafficsaf/improving-traffic-s.html.

[35] Responding to disasters (2013): www3.volvo.com/investors/finrep/sr13/en/creatingvalue/ movingsocietyforwar/engagingwithsociety/respondingtodisaste/responding-to-disas.html.

[36] Corporate social responsibility (2013), p29. 